by chance have some other, unknown action on blood pressure which is not related to the inhibition of converting enzyme that occurs. The fall in blood pressure and in plasma angiotensin II and aldosterone concentrations with MK421 was similar to the falls seen two hours after a single dose of $25 \mathrm{mg}$ of captopril in normotensive subjects." The onset of action of MK421 was slower than with captopril and the duration of action of MK421 as a single dose appears to be longer. A dose of $5 \mathrm{mg}$ of MK421 had the same effect on blood pressure as $20 \mathrm{mg}$. Though an increase in tissue bradykinin cannot be excluded, probably part of the fall in blood pressure seen with MK421 was due to the fall in angiotensin II and aldosterone that occurred.

Angiotensin II has many actions besides those of direct vasoconstriction of the arterioles. It facilitates sympathetic neurotransmission ${ }^{12}$ and increases blood pressure in dogs through an action on the area postrema. ${ }^{13}$ Our results therefore confirm an important role for the renin-angiotensin-aldosterone system in maintaining blood pressure in normotensive subjects receiving a sodium intake of $150 \mathrm{mmol} / \mathrm{day}^{2}$ and illustrate that for a given plasma renin activity the renin system appears to maintain blood pressure to the same extent in patients with essential hypertension. ${ }^{3}$ The renin-angiotensin system can be the cause of high blood pressure only if the concentration of angiotensin II is above normal relative to the sodium balance or there is increased sensitivity to the actions of angiotensin II compared with that in normotensive subjects. Inhibition of angiotensin-converting enzyme, however, is an important mechanism whereby blood pressure may be lowered.

As this non-sulfhydryl-containing enzyme inhibitor lowers blood pressure in normotensive subjects receiving a normal sodium intake, it is probable that like captopril,14 MK421 will be an effective blood-pressure-lowering drug in essential hypertension; MK421, however, will probably have a longer half life. Because it lacks a sulfhydryl group, MK421 possibly may not have some of the problems that have been rarely reported with captopril, such as loss of taste, ${ }^{414}$ membranous glomerulonephritis, ${ }^{5}$ and leukopenia. ${ }^{6}$
These studies were supported by the Medical Research Council and the Wellcome Trust. We are grateful to Mr R N Piasio, Ventrex Corporation, Portland, for supplies of Ventrex kits for measurement of converting-enzyme activity, and to Dr P M Lutterbeck, of Merck Sharp and Dohme Ltd, Zurich, for supplies of MK421.

\section{References}

${ }^{1}$ Haber E. The role of renin in normal and pathological cardiovascular homeostasis. Circulation 1976;54:849-961.

${ }^{2}$ MacGregor GA, Markandu ND, Roulston JE, Jones JC, Morton JJ. Maintenance of blood pressure by the renin angiotensin system in normal man. Nature 1981 ;291:329-31.

${ }^{3}$ MacGregor GA, Markandu ND, Roulston JE. Does the renin-angiotensin system maintain blood pressure in both hypertensive and normotensive subjects? A comparison of propranolol, saralasin and captopril. Clin Sci $1979 ; 57$, suppl No 5:145-8s.

${ }^{4}$ Vlasses PH, Ferguson RK. Temporary ageusia related to captopril. Lancet 1979 ;ii:526.

5 Prins EJL, Hoorntje SJ, Weening JJ, Donker ABJM. Nephrotic syndrome in patient on captopril. Lancet 1979 ;ii:306-7.

${ }^{6}$ Van Brummelen P, Willemze R, Tan WD, Thomson J. Captoprilassociated agranulocytosis. Lancet $1980 ; \mathrm{i}: 150$.

${ }^{7}$ Patchett AA, Harris E, Tristram EW, et al. A new class of angiotensin converting enzyme inhibitors. Nature 1980;288:280-3.

${ }^{8}$ George CF, Lewis PJ, Petrie A. Clinical experience with use of ultrasound sphygmomanometer. Br Heart $\mathcal{F}$ 1975;37:804-7.

${ }^{9}$ Dusterdieck G, McElwee G. Estimation of angiotensin II concentration in human plasma by radioimmunoassay. Some applications to physiological and clinical states. Eur $\mathcal{F}$ Clin Invest 1971 ;2:32-8.

${ }^{10}$ Roulston JE, MacGregor GA. Measurement of plasma renin activity by radioimmunoassay after prolonged cold storage. Clin Chim Acta $1978 ; 88: 45-8$.

11 James VHT, Wilson GA. In: Reid E, ed. Methodological developments in biochemistry. Vol 5. Amsterdam: Elsevier, North-Holland, 1976:149-58.

${ }^{12}$ Clough DP, Hatton R, Conway J, Adigun SA. Angiotensin activates sympathetic reflexes in the anaesthetized cat. Clin Sci 1980;59:287-9s.

13 Joy MD, Lowe RD. Evidence that the area postrema mediates the central cardiovascular response to angiotensin II. Nature 1970;228:1303-4.

${ }^{14}$ MacGregor GA, Markandu ND, Roulston JE, Jones JC. Essential hypertension: effect of an oral inhibitor of angiotensin-converting enzyme. $\operatorname{Br} M e d \mathcal{F} 1979$;ii:1106-9.

(Accepted 5 fune 1981)

\title{
Isolation of Bordetella pertussis from swabs
}

\author{
P W ROSS, C G CUMMING
}

\section{Abstract}

Four varieties of swabs held in plastic containers and three swab transport media kits, all obtainable in the United Kingdom, were tested to assess their effectiveness in the isolation of Bordetella pertussis.

The highest isolation rates up to 48 hours were obtained with Dacron swabs held in plastic containers. Swabtransport media kits proved unsatisfactory.

$B$ pertussis may have a stronger affinity to Dacron than to cotton-wool, and pernasal swabs should be made of Dacron to improve the recovery of $B$ pertussis.

\footnotetext{
Departments of Bacteriology and Oral Medicine and Oral Pathology, University of Edinburgh, Edinburgh EH8 9AG

$\mathrm{P}$ W ROSS, MD, senior lecturer and honorary consultant bacteriologist C G CUMMING, PHD, lecturer in oral medicine and pathology
}

\section{Introduction}

The isolation rate of Bordetella pertussis from patients with whooping cough is disappointingly low. A combined Scottish study ${ }^{1}$ comparing the reliability of serological tests with isolation of the organisms on culture found that the isolation rate was $42 \%$ from infants under 6 months of age; positive results of serological tests were obtained from $19 \%$. In children over 1 year of age the percentage isolated on culture dropped to around $20 \%$, whereas the percentage diagnosed on the basis of serological tests rose to $65 \%$. It was suggested that this change by age was related to previous immunisation. In another study, conducted in Australia over five years, ${ }^{2}$ the isolation rate of $B$ pertussis was only $50 \%$, and because of these generally poor rates it has been recommended that negative results should not exclude infection with these organisms. ${ }^{3}$ The low isolation rate may be due in part to faulty swabbing technique, which is known to affect recovery, ${ }^{4}$ or organisms may die en route to the laboratory. Other factors may include physical retention of organisms on the $\mathrm{swab}^{5}$ and the varieties of swabs or swab transport media kits used. ${ }^{6} 7$

The object of this paper is to report on the efficiency and 
reliability of various fibres used as swab heads and swab transport media kits commercially available for use in the United Kingdom in the recovery of $B$ pertussis on laboratory media.

\section{Materials and methods}

Stock strains of $B$ pertussis obtained from the City Hospital bacteriology laboratory, and the department of bacteriology, University of Edinburgh, were used. Four varieties of swabs held in plastic containers and three swab transport media kits, obtained from commercial sources, were investigated. The four types of swab fibres were: plain, absorbent, buffered cotton-wool; albumin-coated cottonwool; charcoal-coated cotton-wool; and Dacron. The three swab transport media kits were: cotton-wool in Amies medium; cotton-wool in charcoal-Amies medium; and Dacron in charcoal-Amies medium. All were produced in the United Kingdom.

$B$ pertussis strains were grown for $\mathbf{4 8}$ hours in modified Hornibrook medium. ${ }^{8}{ }^{9}$ All swabs were loaded with $0.02 \mathrm{ml}$ of a dilution of the culture and mixed with $0.08 \mathrm{ml}$ pasteurised saliva or saline. Swabs could comfortably take up the $0 \cdot 1 \mathrm{ml}$ volumes. The numbers of organisms loaded on to the swabs were calculated by determining surface-viable counts from $10^{-3}$ to $10^{-5}$ dilutions of the parent culture.

The first series of swabs in plastic containers and those in transport media were plated on to Bordet-Gengou culture medium eight hours after being loaded with a known number of organisms; a second series was similarly plated out after 24 hours and a final series after 48 hours. Equal numbers of swabs contained salivary or saline suspensions and equal numbers were held at room temperature or $4^{\circ} \mathrm{C}$ before being plated out. Surface-viable counts were performed after the plates had been incubated for at least 24 hours.

\section{Results}

The plain cotton-wool swabs fared badly in the tests, both when held in their plastic containers and when held in Amies transport medium. Results were slightly improved when they were immersed in charcoalAmies medium (tables I and II). The albumin-coated swabs were reasonably satisfactory at eight hours but were unreliable after this period. The charcoal-coated swabs produced acceptable results at eight hours, but their performance deteriorated after this time.

Dacron swabs in plastic containers gave the best results up to 48 hours at both temperatures; storage at $4 . \mathrm{C}$ improved the 48 -hour results. The performance of Dacron in charcoal-Amies medium was disastrous (table II).

In most cases, better results were obtained by processing swabs in saline rather than in saliva.

TABLE I-Percentage recovery of $B$ pertussis from swabs not held in transport media

\begin{tabular}{|c|c|c|c|c|c|c|}
\hline & \multicolumn{2}{|c|}{8 Hours } & \multicolumn{2}{|c|}{24 Hours } & \multicolumn{2}{|c|}{48 Hours } \\
\hline & $\begin{array}{l}\text { Room } \\
\text { tempera- } \\
\text { ture }\end{array}$ & $4^{\circ} \mathrm{C}$ & $\begin{array}{l}\text { Room } \\
\text { tempera- } \\
\text { ture }\end{array}$ & $4^{\circ} \mathrm{C}$ & $\begin{array}{l}\text { Room } \\
\text { tempera- } \\
\text { ture }\end{array}$ & $4^{\circ} \mathrm{C}$ \\
\hline $\begin{array}{l}\text { Plain } \\
\text { Albumin } \\
\text { Charcoal } \\
\text { Dacron }\end{array}$ & $\begin{array}{r}0 \\
4 \\
6 \\
12\end{array}$ & $\begin{array}{r}1 \\
7 \\
11 \\
12\end{array}$ & $\begin{array}{l}0 \\
0 \\
1 \\
5\end{array}$ & $\begin{array}{l}0 \\
2 \\
3 \\
3\end{array}$ & $\begin{array}{l}0 \\
0 \\
4 \\
3\end{array}$ & $\begin{array}{l}0 \\
2 \\
1 \\
6\end{array}$ \\
\hline
\end{tabular}

\section{Discussion}

These results indicate that the only fibre that can be recommended for the diagnosis of whooping cough is Dacron, preferably held in a plastic container-particularly if a delay of more than eight hours is expected between taking the swab and processing it in the laboratory. The albumin and charcoal swabs gave reasonable results up to eight hours but not thereafter. Plain cotton-wool swabs cannot be recommended, nor can any of the swab transport media kits.

The results from this study are considerably different from those of previous studies on the isolation of other respiratorytract pathogens from swabs; in those studies the plain and albumin swabs gave acceptable results. ${ }^{5} 7$ Another difference is
TABLE II-Percentage recovery of $B$ pertussis from swabs held in transport media

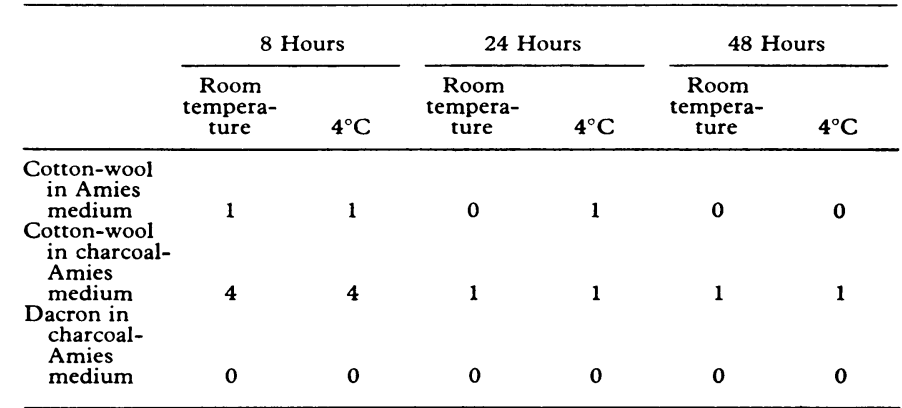

$0=$ counts of organisms rounded to nearest number-that is, $<0.25 \%$ of the original number - as well as no growth.

that in our study saline proved a better vehicle for the organisms than saliva, though a finding common to all the studies was that storage of swabs at $4^{\circ} \mathrm{C}$ produced a better isolation rate.

Rich $^{10}$ showed that $B$ pertussis had a pronounced tendency to attach to the cells of the nasopharynx, and Holt ${ }^{11}$ stated that this adherence depended on a biochemical mechanism analogous to the adsorption of the influenza virus on red blood cells. In contrast to other respiratory-tract pathogens, Bordetella pertussis may therefore have a stronger affinity to Dacron than to plain cotton-wool or to treated cotton-wool.

In Australian studies on whooping cough ${ }^{2}$ varying isolation rates for Bordetella pertussis were found: suggested explanations for this included variations in swabbing techniques and in frequency of swabbing and delays in plating out. Such findings have also been reported in Scottish studies on bacteria from the upper respiratory tract. ${ }^{4} 7$ Other factors may include the amount of the inoculum, the size of the swab head, and also whether a swab is used alone or is immersed in transport medium. ${ }^{6}$ At least one of these variables could be removed, particularly in the diagnosis of whooping cough. These studies indicate that pernasal swabs should be made of Dacron in an attempt to improve the recovery of $B$ pertussis.

We are grateful to $\mathrm{Mr}$ W Adams, computing and statistics group, University of Edinburgh, for statistical analyses; Exogen Ltd, Clydebank, Glasgow, and Medical Wire and Equipment Co, Corsham, Wiltshire, for supplying swabs and swab transport media kits. Financial aid from the following sources is gratefully acknowledged: the Scottish Home and Health Department; the Scottish Hospitals Endowment Research Trust; Abbott Laboratories Ltd; and E R Squibb and Sons.

\section{References}

${ }^{1}$ Public Health Laboratory Service Working Party. Diagnosis of whooping cough: comparison of serological tests with isolation of Bordetella pertussis. A combined Scottish study. Br Med $\mathcal{F} 1970$;iv:637-9.

2 Lewis FA, Gust ID, Bennett NMcK. On the aetiology of whooping cough. f Hyg (Camb) 1973;71:139-44.

3 Duguid JP, Marmion BP, Swain RHA. Medical microbiology. 13th ed. Edinburgh: Churchill Livingstone, 1978.

4 Ross PW. Throat swabs and swabbing technique. Practitioner 1971 ;207: 791-6

5 Ross PW. The isolation of Streptococcus pyogenes from throat swabs. $f$ Med Microbiol 1977;10:69-76.

${ }^{6}$ Cumming CG, Ross PW. Evaluation of bacteriological swabs and transport media in the recovery of group B streptococci on laboratory media. $f$ Clin Pathol 1979;32:1066-9.

${ }^{7}$ Ross PW, Lough H. Survival of upper respiratory tract bacteria on cottonwool swabs. F Clin Pathol 1978;31:430-3.

8 Wardlaw AC, Parton R, Hooker MJ. Loss of protective antigen, histaminesensitising factor and envelope polypeptides in cultural variants of Bordetella pertussis. F Med Microbiol 1975;9:89-100.

${ }^{9}$ Hornibrook JW. Cultivation of phase I Haemophilus pertussis in a semisynthetic liquid medium. Public Health Rep 1939;54:1847.

${ }^{10} \mathrm{Rich}$ AR. On the aetiology and pathogenesis of whooping cough. Bulletin of the Fohns Hopkins Hospital 1932;51:346.

11 Holt LB. The pathology and immunology of Bordetella pertussis infection. f Med Microbiol $1972 ; 5: 407-24$.

(Accepted 18 fune 1981) 